\title{
Quality of Teaching-learning in Undergraduate Medical Education in Bangladesh - Views of Stakeholders
}

\author{
Uddin $M N^{1}$, Asaduzzaman AKMㄴ, Talukder $M H K^{3}$ and Giti $S^{4}$
}

\begin{abstract}
This descriptive type of cross-sectional study was carried out in 4 government and 4 nongovernment medical colleges of Bangladesh to assess the quality of undergraduate medical education. The study was conducted during the period of July 2018 to June 2019. The total sample size was 576 , out of which there were 440 fifth year medical students, 114 clinical teachers and 22 Key informants. Convenience sampling technique was adopted. Two self administered semi- structured questionnaires and one in-depth-interview schedule were utilized for the study. The study revealed that there was shortage of teaching staffs and infrastructure facilities. However numbers of hospital beds, indoor and outdoor patients were found to be sufficient. Study revealed that most of the students learned to take history, examine the patients; but had difficulties to make a provisional diagnosis. The clinical teaching in evening session was found to be neglected. Teachers could not ensure students' learning of optimum skills and attitude. The study recommended reviewing the curriculum. Course burden should be reduced by removing redundant contents. The subjects namely Pathology, Microbiology and Pharmacology need to be rearranged to shift those to second phase. Emphasis is required to be given on behavioural science, communication skills and medical ethics.
\end{abstract}

Keywords: Current situation, undergraduate medical education, Stakeholder

1. Dr. Md Nizam Uddin, Principal, Rangpur Army Medical College.

2. Prof. Dr. AKM Asaduzzaman, Professor, Community Medicine, Diabetic Association Medical College, Faridpur.

3. Professor Dr. Md. Professor (Curriculum Development and Evaluation) Centre for Medical Education (CME), Dhaka.

4. Major Gen. (Dr) Susane Giti, Commandant, Armed Forces Institute of Pathology, Dhaka Cantonment

Address of correspondence: Dr. Md Nizam Uddin, Principal and Professor of Microbiology, Rangpur Army Medical College. email: ishmum.652@gmail.com

\section{Introduction}

Medical education is education related to the practice of being a medical practitioner; either the initial training to become a physician (i.e. medical schooland internship), or additional training thereafter (e.g. residency, fellowship and continuing medical education $)^{1}$. In medical education, quality can be considered at both the creation of the next generation of appropriate medical graduates and the

Bangladesh Journal of Medical Education 2020; 11(2);Uddin et al., publisher and licensee Association for Medical Education. This is an Open Access article which permits unrestricted non-commercial use, provided the original work is properly cited. maintenance of the values and principles of the medical institutions ${ }^{2}$.

Globalization of medicine is increasing, as manifested by growing number of migrating doctors and cross border education providers 3 . The improved health for all is the overall mission of the World Federation for Medical Education (WFME). The 2015 revision of the WFME global standards recommended 106 
basic standards, 90 quality development standards and 127 annotations ${ }^{4}$.

First formal medical curriculum was published in Bangladesh in 1988..$^{5}$ But after evaluation it was revealed that there was room for much improvement. After a series of workshops, Undergraduate Medical Curriculum 2002 was developed and implemented. The updated MBBS Curriculum 2012 began its journey with the inclusion of national goal, objectives, learning outcomes and competencies. ${ }^{6}$ At present there are 111 medical colleges in Bangladesh of which 37 are government and the rest 74 are private medical colleges. There is a growing concern regarding the overall quality of teaching, learning and assessment. ${ }^{7}$ The quality of medical education is getting compromised in Bangladesh due to inadequate hospital facilities and shortage of teachers, libraries and laboratories. Many medical colleges have none to teach the basic and para -clinical subjects for the MBBS students ${ }^{8}$. According to a report about 50 per cent or more positions of medical teachers are currently vacant at government and private medical colleges. ${ }^{8}$ With the present scenario it is very difficult to maintain the optimum standards of teaching in undergraduate medical education. In view of the above, this study made an attempt to assess the overall quality of teaching-learning in undergraduate medical education in Bangladesh by analyzing the views of stakeholders namely policy makers, teachers and students.

\section{Materials and Methods}

This descriptive cross sectional study was conducted with the objective to assess the quality teaching in 4 government and 4 nongovernment medical colleges in Bangladesh. The study was conducted during the period of July 2018 to June 2019 . The total sample size was 576 , out of which there were 114 clinical teachers, 440 fifth year students of selected medical.

\section{Results}

Table -1 showed the views of students in relation to the quality of teaching. Students stated that the number of subject specialist teachers was adequate $(63.2 \%)$; teachers took class in the morning shift $(90 \%)$; teachers took class in the evening shift colleges, and 22 key informants. Convenience sampling method was adopted to collect the data. Two self-administered semi structured questionnaires were used for teachers and students; one in-depth-interview schedule for each key informant. Data derived from questionnaires were processed and analyzed by SPSS and those obtained from in-depthinterview were categorized and summarized. $(61.3 \%)$; teachers supported the students' difficulties (33.6); teachers were dedicated to address the students' needs $(35.5 \%)$; teachers provided due importance to the students opinion $(37.5 \%)$

Bangladesh Journal of Medical Education 2020; 11(2);Uddin et al., publisher and licensee Association for Medical Education. This is an Open Access article which permits unrestricted non-commercial use, provided the original work is properly cited. 
Table 1: Distribution of the students as per their views in relation to the quality of teaching and learning $(n=440)$

\begin{tabular}{|c|c|c|c|c|c|}
\hline \multirow[b]{2}{*}{ Statements } & \multicolumn{5}{|c|}{ Level of agreement } \\
\hline & $\begin{array}{l}\text { SDA } \\
\text { f(\%) }\end{array}$ & $\begin{array}{c}\text { DA } \\
\mathbf{f}(\%)\end{array}$ & $\begin{array}{c}\text { NAND } \\
\mathbf{f}(\%)\end{array}$ & $\begin{array}{c}\mathrm{A} \\
\mathbf{f}(\%)\end{array}$ & $\begin{array}{c}\mathbf{S A} \\
\mathbf{f}(\%)\end{array}$ \\
\hline $\begin{array}{l}\text { The number of subject specialist } \\
\text { teachers was adequate }\end{array}$ & $\begin{array}{c}63 \\
(14.3)\end{array}$ & $\begin{array}{c}77 \\
(17.5)\end{array}$ & $22(5.0)$ & $\begin{array}{c}193 \\
(43.9)\end{array}$ & $\begin{array}{c}85 \\
(19.3)\end{array}$ \\
\hline $\begin{array}{l}\text { Knowledge, skill and attitude } \\
\text { of teachers were optimum }\end{array}$ & $25(5.7)$ & $\begin{array}{c}60 \\
(13.6)\end{array}$ & $\begin{array}{c}70 \\
(15.9)\end{array}$ & $\begin{array}{c}217 \\
(49.3)\end{array}$ & $\begin{array}{c}68 \\
(15.5)\end{array}$ \\
\hline $\begin{array}{l}\text { Teachers took class in morning } \\
\text { shift according to routine }\end{array}$ & $8(1.8)$ & $12(2.7)$ & $24(5.5)$ & $\begin{array}{c}228 \\
(51.8)\end{array}$ & $\begin{array}{c}168 \\
(38.2)\end{array}$ \\
\hline $\begin{array}{l}\text { Teachers took class in evening } \\
\text { shift according to routine }\end{array}$ & $43(9.8)$ & $\begin{array}{c}60 \\
(13.6)\end{array}$ & $\begin{array}{c}67 \\
(15.2)\end{array}$ & $185(42)$ & $\begin{array}{c}85 \\
(19.3)\end{array}$ \\
\hline $\begin{array}{l}\text { In most of the times teachers } \\
\text { supported the students' difficulties }\end{array}$ & $\begin{array}{c}92 \\
(20.9)\end{array}$ & $\begin{array}{c}103 \\
(23.4)\end{array}$ & $\begin{array}{l}97 \\
(22.0)\end{array}$ & $\begin{array}{c}129 \\
(29.3)\end{array}$ & $19(4.3)$ \\
\hline $\begin{array}{l}\text { Teachers were dedicated to } \\
\text { address the students' needs }\end{array}$ & $\begin{array}{c}63 \\
(14.3)\end{array}$ & $\begin{array}{c}130 \\
(29.5)\end{array}$ & $\begin{array}{c}91 \\
(20.7)\end{array}$ & $\begin{array}{c}131 \\
(29.8)\end{array}$ & $25(5.7)$ \\
\hline $\begin{array}{l}\text { Teachers provided due } \\
\text { importance to the students } \\
\text { opinion }\end{array}$ & $\begin{array}{c}67 \\
(15.2)\end{array}$ & $\begin{array}{c}111 \\
(25.2)\end{array}$ & $\begin{array}{c}97 \\
(22.0)\end{array}$ & $\begin{array}{c}144 \\
(32.7)\end{array}$ & $\begin{array}{c}21 \\
(4.8)\end{array}$ \\
\hline
\end{tabular}

Table 2 shows the distribution of the medical teachers as per their views in relation to the quality of teaching and learning. It shows that total $48.2 \%$ teachers disagreed $(25.4 \%$ strongly disagreed; $22.8 \%$ disagreed) with the adequacy of subject specialist teachers. Teachers took class in evening shift $(56.1 \%)$.

Bangladesh Journal of Medical Education 2020; 11(2);Uddin et al., publisher and licensee Association for Medical Education. This is an Open Access article which permits unrestricted non-commercial use, provided the original work is properly cited. 
Original Article

Table 2: Distribution of the medical teachers as per their views in relation to the quality of teaching and learning $\quad(n=114)$

\begin{tabular}{|c|c|c|c|c|c|}
\hline \multirow[t]{2}{*}{ Statements } & \multicolumn{5}{|c|}{ Level of agreement } \\
\hline & $\begin{array}{l}\text { SDA } \\
\text { f(\%) }\end{array}$ & DA f(\%) & $\begin{array}{l}\text { NAND } \\
\text { f( } \%)\end{array}$ & $\begin{array}{c}\mathrm{A} \\
\mathbf{f}(\%)\end{array}$ & $\begin{array}{c}\text { SA } \\
\mathbf{f}(\%)\end{array}$ \\
\hline $\begin{array}{l}\text { The number of subject specialist } \\
\text { teachers was adequate }\end{array}$ & $\begin{array}{c}29 \\
(25.4)\end{array}$ & $26(22.8)$ & $3(2.6)$ & $41(36.0)$ & $\begin{array}{c}15 \\
(13.2)\end{array}$ \\
\hline $\begin{array}{l}\text { Knowledge, skill and attitude of } \\
\text { teachers were optimum. }\end{array}$ & $6(5.3)$ & $16(14.0)$ & $10(8.8)$ & $65(57.0)$ & $\begin{array}{c}17 \\
(14.9)\end{array}$ \\
\hline $\begin{array}{l}\text { Teachers took class in morning } \\
\text { shift according to routine. }\end{array}$ & $4(3.5)$ & $2(1.8)$ & $7(6.1)$ & $44(38.6)$ & $\begin{array}{c}57 \\
(50.0)\end{array}$ \\
\hline $\begin{array}{l}\text { Teachers took class in evening } \\
\text { shift according to routine. }\end{array}$ & $10(8.8)$ & $\begin{array}{c}22 \\
(19.3) \\
\end{array}$ & $18(15.8)$ & $\begin{array}{c}39 \\
(34.2) \\
\end{array}$ & $\begin{array}{c}25 \\
(21.9) \\
\end{array}$ \\
\hline $\begin{array}{l}\text { In most of the times teachers } \\
\text { supported the students' } \\
\text { difficulties. }\end{array}$ & $2(1.8)$ & $3(2.6)$ & $15(13.2)$ & $69(60.5)$ & $\begin{array}{c}25 \\
(21.9)\end{array}$ \\
\hline $\begin{array}{l}\text { Teachers were dedicated to } \\
\text { address the students' needs. }\end{array}$ & $3(2.6)$ & $7(6.1)$ & $9(7.9)$ & $61(53.5)$ & $\begin{array}{c}34 \\
(29.8)\end{array}$ \\
\hline $\begin{array}{l}\text { Teachers provided due } \\
\text { importance to the students } \\
\text { opinion }\end{array}$ & $5(4.4)$ & $3(2.6)$ & $8(7.0)$ & $64(56.1)$ & $\begin{array}{c}34 \\
(29.8)\end{array}$ \\
\hline
\end{tabular}

Table 3 shows that total $66.7 \%$ students stated that the capacities of lecture galleries were sufficient. Audio-visual aids used in lecture galleries are of appropriate quality and quantity (48.6\%), physical space available for practical class is appropriate
(40\%), practical appliances are of good quality and quantity (38.\%). In other issues the students' opinions were divided. Total $54.7 \%, 61.6 \%$ and $62.1 \%$ students agreed that the numbers of hospital beds, indoor and outdoor patients respectively were sufficient.

Table 3: Distribution of the students as per their views in relation to the structural and logistic support for quality teaching and learning

\begin{tabular}{|l|c|c|c|c|c|}
\hline \multicolumn{1}{|c|}{ Statement } & \multicolumn{5}{c|}{ Level of agreement } \\
\cline { 2 - 6 } & SDA & DA & NAND & A & SA \\
\cline { 2 - 7 } & f(\%) & f(\%) & $\mathbf{f}(\%)$ & f $(\%)$ & f(\%) \\
\hline The capacities of lecture \\
galleries were sufficient. & $60(13.6)$ & 69 & $13(3.0)$ & 180 & 118 \\
$(40.9)$ & $(26.8)$ \\
\hline The lecture galleries had & $94(21.4)$ & 89 & $23(5.2)$ & 149 & 85
\end{tabular}

Bangladesh Journal of Medical Education 2020; 11(2);Uddin et al., publisher and licensee Association for Medical Education. This is an Open Access article which permits unrestricted non-commercial use, provided the original work is properly cited. 
Original Article

\begin{tabular}{|c|c|c|c|c|c|}
\hline $\begin{array}{l}\text { sufficient lighting, ventilation } \\
\text { and seating arrangement. }\end{array}$ & & $(20.2)$ & & (33.9) & (19.3) \\
\hline $\begin{array}{l}\text { Audio-visual aids used in } \\
\text { lecture galleries were } \\
\text { appropriate }\end{array}$ & $83(18.9)$ & $\begin{array}{c}111 \\
(25.2)\end{array}$ & $\begin{array}{c}111 \\
(25.2)\end{array}$ & $\begin{array}{c}129 \\
(29.3)\end{array}$ & $\begin{array}{c}129 \\
(29.3)\end{array}$ \\
\hline $\begin{array}{l}\text { The physical space for tutorial } \\
\text { class was appropriate. }\end{array}$ & \begin{tabular}{|l}
$75(17.0)$ \\
\end{tabular} & $\begin{array}{c}75 \\
(17.0)\end{array}$ & $\begin{array}{c}54 \\
(12.3)\end{array}$ & $\begin{array}{c}144 \\
(32.7)\end{array}$ & $\begin{array}{c}144 \\
(32.7)\end{array}$ \\
\hline $\begin{array}{l}\text { Audio-visual aids in tutorial } \\
\text { class were appropriate }\end{array}$ & $116(26.4)$ & $\begin{array}{c}144 \\
(32.7)\end{array}$ & $\begin{array}{c}144 \\
(32.7)\end{array}$ & $\begin{array}{c}144 \\
(32.7)\end{array}$ & $\begin{array}{c}144 \\
(32.7)\end{array}$ \\
\hline $\begin{array}{l}\text { The physical space available } \\
\text { for practical class was } \\
\text { appropriate. }\end{array}$ & $83(18.9)$ & $\begin{array}{c}122 \\
(27.7)\end{array}$ & $\begin{array}{c}59 \\
(13.4)\end{array}$ & $\begin{array}{c}142 \\
(32.3)\end{array}$ & $34(7.7)$ \\
\hline $\begin{array}{l}\text { The practical appliances were of good } \\
\text { quality and quantity }\end{array}$ & $74(16.8)$ & $\begin{array}{c}127 \\
(28.9)\end{array}$ & $72(16.4)$ & $\begin{array}{c}134 \\
(30.5)\end{array}$ & $33(7.5)$ \\
\hline $\begin{array}{l}\text { The number hospital beds is sufficient } \\
\text { for clinical teaching and learning. }\end{array}$ & $85(19.3)$ & $75(17.0)$ & $39(8.9)$ & 192(43.6) & $49(11.1)$ \\
\hline $\begin{array}{l}\text { The number of outdoor patients is } \\
\text { sufficient for clinical teaching. }\end{array}$ & $77(17.5)$ & $54(12.3)$ & $38(8.6)$ & 193(43.9) & $78(17.7)$ \\
\hline $\begin{array}{l}\text { The number of indoor patients is } \\
\text { sufficient for clinical teaching. }\end{array}$ & $62(14.1)$ & $54(12.3)$ & $51(11.6)$ & 201(45.7) & $72(16.4)$ \\
\hline
\end{tabular}

Table 4 shows that total $61.4 \%$ teachers agreed that the capacities of lecture galleries were sufficient. The lecture galleries had sufficient lighting, ventilation and seating arrangement (38.6\% agreed; $9.6 \%$ strongly agreed). The physical space for tutorial class was appropriate $(25.4 \%$ disagreed; $8.8 \%$ strongly disagreed). Audio-visual aids used in tutorial class were of appropriate quality and quantity. (28.9\% disagreed; $7.0 \%$ strongly disagreed). Tutorial classes were mostly taken by the senior teachers (10.5\% strongly disagreed; $26.3 \%$ disagreed). The physical space available for practical class was appropriate $(7.9 \%$ strongly disagreed; $23.7 \%$ disagreed). The practical appliances were of good quality and quantity (11.4\% strongly disagreed; $21.9 \%$ disagreed). Total 58.7\%, 61.5\% and $73.7 \%$ teachers were satisfied with the number of hospital beds, number of indoor and outdoor patients respectively related to clinical teaching.

Bangladesh Journal of Medical Education 2020; 11(2);Uddin et al., publisher and licensee Association for Medical Education. This is an Open Access article which permits unrestricted non-commercial use, provided the original work is properly cited. 
Table 4: Distribution of the medical teachers as per their views in relation to the structural and logistic support $\quad(n=114)$

\begin{tabular}{|c|c|c|c|c|c|}
\hline \multirow[t]{2}{*}{ Statement } & \multicolumn{5}{|c|}{ Level of agreement } \\
\hline & $\begin{array}{l}\text { SDA } \\
\text { f(\%) } \\
\end{array}$ & $\begin{array}{c}\text { DA } \\
\mathbf{f}(\%)\end{array}$ & $\begin{array}{l}\text { NAND } \\
\mathbf{f}(\%)\end{array}$ & $\begin{array}{c}\mathbf{A} \\
\mathbf{f}(\%)\end{array}$ & $\begin{array}{c}\text { SA } \\
\mathbf{f}(\%)\end{array}$ \\
\hline $\begin{array}{l}\text { The capacities of lecture } \\
\text { galleries were sufficient. }\end{array}$ & $8(7.0)$ & $23(20.2)$ & $13(11.4)$ & $49(43.0)$ & $21(18.4)$ \\
\hline $\begin{array}{l}\text { The lecture galleries had } \\
\text { sufficient lighting, ventilation } \\
\text { and seating arrangement. }\end{array}$ & $7(6.1)$ & $31(27.2)$ & $21(18.4)$ & $44(38.6)$ & $11(9.6)$ \\
\hline $\begin{array}{l}\text { Audio-visual aids used in } \\
\text { lecture galleries were appropriate }\end{array}$ & $7(6.1)$ & $22(19.3)$ & $20(17.5)$ & $49(43.0)$ & $16(14.0)$ \\
\hline $\begin{array}{l}\text { The physical space for tutorial } \\
\text { class was appropriate. }\end{array}$ & $10(8.8)$ & $29(25.4)$ & $14(12.3)$ & $47(41.2)$ & $14(12.3)$ \\
\hline $\begin{array}{l}\text { Audio-visual aids used in } \\
\text { tutorial class were appropriate }\end{array}$ & $8(7.0)$ & $33(28.9)$ & $14(12.3)$ & $49(43.0)$ & $10(8.8)$ \\
\hline $\begin{array}{l}\text { Tutorial classes were mostly } \\
\text { taken by the senior teachers. }\end{array}$ & $\begin{array}{c}12 \\
(10.5) \\
\end{array}$ & $30(26.3)$ & $24(21.1)$ & $43(37.7)$ & $5(4.4)$ \\
\hline $\begin{array}{l}\text { The physical space available } \\
\text { for practical class was } \\
\text { appropriate. }\end{array}$ & $9(7.9)$ & $27(23.7)$ & $19(16.7)$ & $49(43.0)$ & $10(8.8)$ \\
\hline $\begin{array}{l}\text { The practical appliances were of } \\
\text { good quality and quantity. }\end{array}$ & $\begin{array}{c}13 \\
(11.4)\end{array}$ & $25(21.9)$ & $23(20.2)$ & $44(38.6)$ & $9(7.9)$ \\
\hline $\begin{array}{l}\text { The number hospital beds are sufficient } \\
\text { for clinical teaching and learning. }\end{array}$ & $\begin{array}{c}13 \\
(11.4)\end{array}$ & $\begin{array}{c}21 \\
(18.4)\end{array}$ & $\begin{array}{c}13 \\
(11.4)\end{array}$ & $\begin{array}{c}51 \\
(44.7) \\
\end{array}$ & $\begin{array}{c}16 \\
(14.0)\end{array}$ \\
\hline $\begin{array}{l}\text { The number of indoor patients is } \\
\text { sufficient for clinical teaching. }\end{array}$ & $\begin{array}{c}7 \\
(6.1)\end{array}$ & $\begin{array}{c}25 \\
(21.9)\end{array}$ & $\begin{array}{c}12 \\
(10.5)\end{array}$ & $\begin{array}{c}46 \\
(40.4)\end{array}$ & $\begin{array}{c}24 \\
(21.1)\end{array}$ \\
\hline $\begin{array}{l}\text { The number of outdoor patients is } \\
\text { sufficient for clinical teaching. }\end{array}$ & $\begin{array}{c}6 \\
(5.3) \\
\end{array}$ & $\begin{array}{c}15 \\
(13.2)\end{array}$ & $\begin{array}{c}9 \\
(7.9) \\
\end{array}$ & $\begin{array}{c}44 \\
(38.6) \\
\end{array}$ & $\begin{array}{c}40 \\
(35.1)\end{array}$ \\
\hline
\end{tabular}

\section{Summary of in-depth-interviews with policymakers and senior clinical medical teachers)}

The study collected the opinions of key informants. After transcription, categorization and condensation, summary reports of opinions are as follows-
1. The curriculum needs to be evaluated within short period of time. Core contents should be emphasized and course burden should be reduced by removing redundant chapters.

2. Course allocation of the subjects namely Pathology, Microbiology and Pharmacology should be rearranged to second phase.

Bangladesh Journal of Medical Education 2020; 11(2);Uddin et al., publisher and licensee Association for Medical Education. This is an Open Access article which permits unrestricted non-commercial use, provided the original work is properly cited. 
3. Emphasis to be given to behavioural science, communication skills and medical ethics.

4. Professionalism in medical education should be emphasized.

5. Resources of medical colleges should be reviewed and strict control should be applied on medical colleges which failed to meet the national standards.

6. Medical Education units should be made fully functional and National Quality Assurance Body should be further strengthened with appropriate resources.

7. Emphasis should be given to small group teaching.

8. Student-teacher interrelationship should be improve

\section{Discussion}

This descriptive type of cross-sectional study was conducted during the period of July 2018 to June 2019. Out of total 440 students 193 $(43.9 \%)$ agreed and $85(19.3 \%)$ strongly agreed that there was enough number of subject specialist teachers (Table 1). This does not correspond to the recent report that 50 per cent or more positions of professors, associate professors and assistant professors are currently vacant at government and private medical colleges. ${ }^{8}$ However on the same issue, teachers' agreements were much less; $36.0 \%$ and $13.2 \%$ respectively (Table 2 ). The opinion of the students in this issue may be subjected to the inexperience of the medical students. In the present study it was revealed that most of the teachers took class in the morning shift but much less in the evening (Table $1 \&$ Table 2). This may be related to the private practice of the clinical teachers in the evening. Teacher shortage is also major issue. A study revealed that the mean scores on duration of bedside teaching including evening session was low due to several causes related to teachers and students $^{9,10}$. In this study according to the opinion of the students, majority of the teachers were not found to be dedicated to students' needs (Table 1). Teachers' lack of commitments, shortage of teachers and excess load of patients may be the underlying reasons. In a similar study it was reported that excess clinical load, administrative work and existing socio-political environment hampered their teaching roles ${ }^{11}$. In regards to the structural and logistic support, the students' opinions were divided. But both the students and teachers agreed that the physical space for practical class and the quantity and quality of practical appliances used were not appropriate (Table 3 \& Table 4). Only 42.1\% teachers mentioned that tutorial classes were mostly taken by senior teachers (Table 4). Constraints such as lack of structural uniformity, financial and resource limitations for teaching in small groups, and short supply of dependable peer tutors are a few recognized challenges. ${ }^{12}$ Some recent reports, stated that newly formed government medical colleges and many private medical colleges lacked adequate support system for proper medical education ${ }^{7,13}$. In regards to clinical teaching, both the students and teachers opined that the numbers of hospital beds, indoor and outdoor patients were sufficient (Table 3 and Table 4). The findings are not in agreement with a report that many private medical colleges and newly formed government medical colleges lack sufficient hospital facilities related to clinical teaching 7,8 . The variation in observations may be related to the lack of awareness of the respondents in regards to the national and global standards set for medical education.

\section{Conclusion}

Obtaining the optimum quality of undergraduate medical education is a challenge in a resource-poor setting like Bangladesh. This study revealed that there was shortage of subject specialist teachers, infrastructure facilities especially those for

Bangladesh Journal of Medical Education 2020; 11(2);Uddin et al., publisher and licensee Association for Medical Education. This is an Open Access article which permits unrestricted non-commercial use, provided the original work is properly cited. 
tutorial and practical classes. The clinical teaching in evening session was found to be neglected and most of the students faced difficulties to make a provisional diagnosis. Newly passed graduates had satisfactory levels of knowledge but their related skills and attitude need to be improved. The number of patients and patient flow in private medical colleges was not satisfactory. The curriculum needs to be evaluated within short period of time. In the context of the above scenario the question is-are we prepared to meet the ever-growing demand of the health sector in our society?

\section{References:}

1. Wikipedia 2018. Medical education, the free encyclopedia. https://en.wikipedia. org/wiki /Medical_education. Visited on 17 April 2018.

2. Gale R, Grant J, 2011. Quality Assurance Systems for Medical Education. Chap. 13. [Last cited 2011 Dec 20]. Available from: http://www.radcliffeoxford.com/./RAD-WALSH-CH131d125ce0rdz.pdf .

3. Karle H 2006. Global Standards and Accreditation in Medical education. A View from WFME ${ }^{e e}$ Supplement on the Occasion of the ECFMG 50th Anniversary Invitational Conference "Impact of International Medical Graduates on US and Global Health Care" Academic Medicine, vol. 81(Suppl)pp.43-48.

4. WFME 2015, Global Standards for Quality Improvement. The 2015
Revision. WFME Office Ferney-

Voltaire, France Copenhagen, Denmark.

5. Majumder MAA 2003. "Medical Education in Bangladesh: Past Successes, Future Challenges". Bangladesh Medical Journal 2003; 32:37-39.

6. Curriculum for undergraduate medical education in Bangladesh-updated 2012. Bangladesh Medical and Dental Council (BMDC).www.bmdc.org.bd

7. Rahman M, 2018. More Medical Colleges, but What about Quality? Prothom Alo Daily news paper. Update: 14:48, Aug 28, 2018. Print.

8. Alamgir M \& Alam SA, 2018. Medical Education Quality in Bangladesh Dips due to Shortage of Teachers, Facilities. New Age, Published: 23:06, Jun 02, | Updated: 12:42, Jun 03, Print.

9. Sultana J, Ara I, Talukder HK and Khan MMH, 2013. Current Practice of Bedside Teaching in Undergraduate Medical Education of Bangladesh. Bangladesh Journal of Medical Education;4(1):2-7.

10. Peters M, Cate OT. Bedside teaching in medical education: a literature review Perspect Med Educ. 2014 Apr;3(2):7688. doi: 10.1007/s40037-013-0083-y.

11. Shamsuddin AKM ,Talukder HK, Nargis T, Alam K, Sultana N, 2015. Roles performed by Clinical Teachers in Undergraduate Medical Education of Bangladesh. Bangladesh Journal of Medical Education.Vol.- 06, Issue01,2015

12. Srivastava TK and Waghmare LS. Tutorial in medical education: A review of contextual modifications. Natl J Physiol Pharm Pharmacol

Bangladesh Journal of Medical Education 2020; 11(2);Uddin et al., publisher and licensee Association for Medical Education. This is an Open Access article which permits unrestricted non-commercial use, provided the original work is properly cited. 
2016;6 (Online First).Doi:10 .5455/ njppp.2017.7.08234030920

13. Hasan S. Medical education in Bangladesh and its impact on doctors and patients. The Independent; 9 June, 2018 00:00 00 AM / LAST MODIFIED: 8 June, 2018 11:57:56

PM, Print.

Bangladesh Journal of Medical Education 2020; 11(2);Uddin et al., publisher and licensee Association for Medical Education. This is an Open Access article which permits unrestricted non-commercial use, provided the original work is properly cited. 